\title{
THE EFFECT OF SEASONAL CHANGES ON FRESHWATER FISH ASSEMBLAGES AND ENVIRONMENTAL FACTORS IN BUKIT MERAH RESERVOIR (MALAYSIA)
}

\author{
Zakeyuddin MOHD SHAFIQ *, Md Sah AMIR SHAH RUDDIN *, \\ Hazrin Hashim ZARUL *, Puteh KHALED *, \\ Mohammad SYAIFUL ** and Wan Omar WAN MAZNAH *
}

\begin{abstract}
* University Sains Malaysia, School of Biological Sciences, Minden, Penang, Malaysia, MY-11800, shafiqzakeyuddin@gmail.com, amirshah@usm.my, zarul@usm.my, wmaznah@usm.my

** Pulau Banding Rainforest Research Center, Pulau Banding, Gerik, Perak, Malaysia, MY-33300, sifu_nyetok@yahoo.com
\end{abstract}

DOI: 10.1515/trser-2015-0005

KEYWORDS: Malaysia, Bukit Merah Reservoir, seasonal changes, freshwater fish, environmental factors.

\section{ABSTRACT}

Seasonal changes of freshwater fish assemblages and environmental factors in Bukit Merah Reservoir were carried out from January-February 2013 (dry season) to March-April 2013 (wet season) by measuring several physico-chemical parameters such as dissolved oxygen (DO), water temperature, $\mathrm{pH}$, water conductivity, total dissolved solids (TDS) and water clarity. 19 fish species comprising of 10 families were collected by using experimental gill nets with different mesh sizes at four different sampling stations. Mean CPUE for total catch and biomass were significantly different between dry and wet season $(p<0.05)$. Based on a T-test analysis, water temperature, $\mathrm{pH}$ and conductivity were significantly different $(p<$ 0.05 ) between seasons whereas a one-way ANOVA displayed a significant difference in TDS and water clarity between sampling stations $(p<0.05)$, implicating that those factors did not give major influence towards other parameters in a man-made reservoir. From all fish species studied, only mean CPUE for individuals (CPUEn) of Osteochilus vittatus and Oxygaster anomalura had a significant difference between seasons $(p<0.05)$; probably an indicator of their migration season.

ZUSAMMENFASSUNG: Auswirkungen saisonaler Schwankungen in Gemeinschaften von Süßwasserfischen und Umweltfaktoren im Bukit Merah Speicher (Malaysia).

Saison gebundene Schwankungen in Gemeinschaften von Süßwasserfischen und Umweltfaktoren wurden im Bukit Merah Speicher von Januar-Februar 2013 (Trockenzeit) bis März-April 2013 (Regenzeit) untersucht. Dabei wurden einige physikalisch-chemische Parameter wie gelöster Sauerstott (DO), Wassertemperatur, pH, Leitfähigkeit, gelöste Feststoffe insgesamt (TDS) und Wassertransparenz gemessen. 19 Fischarten aus 10 Familien wurden mit Kiemennetzen unterschiedlicher Maschenweite an vier Probestellen gesammelt. Der mittlere CPUE-Wert für den Gesamtfang und die Biomasse war signifikant unterschiedlich in der Trocken- und Regenzeit $(p<0,05)$. Auf Grund einer T-Test Analyse zeigten sich bei Wassertemperatur, $\mathrm{pH}$ und Leitfähigkeit signifikante Unterschiede $(p<0,05)$ 
zwischen Trocken- und Regenzeit, während TDS und Wassertransparenz nur signifikante Unterschiede zwischen den Probestellen $(p<0,05)$ von einem Einweg ANOVA zeigten, woraus sich ergibt, dass diese Faktoren keinen großen Einfluss gegenüber anderen Parametern in einem künstlichen Wasserspeicher haben. Von allen untersuchen Fischarten war allein der mittlere CPUE-Wert für Individuen (CPUEn) bei Osteochilus vittatus und Oxygaster anomalura signifikant unterschiedlich zwischen den beiden Jahreszeiten $(p<0,05)$, was wohl ein Indikator für deren Migrationszeit ist.

REZUMAT: Efectul schimbărilor sezoniere asupra ihtiocomunităților dulcicole și a factorilor de mediu în lacul de acumulare Bukit Merah (Malaezia).

Prezentul articol se bazează pe cercetări efectuate din lunile ianuarie-februarie 2013 (sezonul secetos) în martie-aprilie 2013 (sezonul umed) prin măsurarea parametrilor fizicochimici, precum oxigenul dizolvat (DO), temperatura, transparența și conductivitatea apei, $\mathrm{pH}$, materia solidă dizolvată totală (TDS). 19 specii de pești din 10 familii au fost colectate cu ajutorul unor plase experimentale cu diferite mărimi ale ochiurilor în patru stații de eșantionare diferite. CPUE mediu pentru captura totală și biomasa au diferit semnificativ între sezonul secetos şi cel umed $(p<0,05)$. Conform analizei T-test, temperatura, conductivitatea şi $\mathrm{pH}$-ul au variat semnificativ $(p<0,05)$ de la un sezon la altul în timp ce TDS și transparența au variat semnificativ de la o stație la alta $(p<0,05)$ după ANOVA, ceea ce înseamnă că acești factori nu au avut influență majoră față de alți parametri în acest lac artificial. Dintre toate speciile studiate, doar CPUE mediu individual (CPUEn) la Osteochilus vittatus și Oxygaster anomalura au variat semnificativ între sezoane $(p<0,05)$, probabil indicând sezonul de migrație.

\section{INTRODUCTION}

One of the biggest challenges of conserving or restoring the source of water is to adequately understand the relationship between physico-chemical environment, including seasonal and annual variations, and interactions among species in the reservoir. Generally, the wetland areas in Malaysia are struggling from resource degradation and have negative impacts on the local communities (Ambak and Jalal, 2006; Alang et al., 2010; Aziz and Hashim, 2011).

The conversion of the catchment area for agricultural and urbanization use affects the quality and quantity of water. Water degradation in most lakes is often associated with higher presence of nutrients (phosphorous, nitrogen and ammonia) in the water. Deterioration in water quality directly or indirectly affects fish physiology and growth.

Many countries are facing water shortage due to increasing demand of freshwater as a result of population pressure and water pollution. In a developing country that has limited food production, reservoirs act as a supplemental water source for agriculture (Easton and Petrovic, 2004; Akinbile et al., 2013). Apart from agricultural purposes, they also serve as habitats for wildlife, including endemic and endangered species (Akinbile et al., 2013). Since the demand of water in Malaysia is increasing, about 73 lakes have been created to supply the nation's demand (Sharip and Zakaria, 2008; Akinbile et al., 2013).

However, there are significant anthropogenic interventions occurring such as eutrophication, sedimentation, weed infestation and deterioration in water quality. Seasonal variation and human activities are major factors influencing fish assemblages and abiotic factors in the shallow reservoir. Thus, the objective of the present study is to determine the effect of seasonal changes on fish assemblages and environmental factors in Bukit Merah Reservoir. 


\section{MATERIALS AND METHODS}

Bukit Merah Reservoir (BMR - $5^{\circ} 01^{\prime} \mathrm{N} 100^{\circ} 39^{\prime} \mathrm{E}$ ), which covers an area of $40 \mathrm{~km}^{2}$, is a man-made lake and one of the oldest reservoirs located in the district of Kerian, Perak (Ismail and Najib, 2011). BMR is divided into two parts; the north lake and the south lake, by a $4.7 \mathrm{~km}$ railway line (Ismail and Najib, 2011). The water sources spring from two main catchment areas, namely Merah and Kurau basins. However, there are several tributaries, including the Ara, Jelutong and Selarong rivers, that link up with the basin. Water from the reservoir is channelled out by gravity flow through six gates into two outlet canals, the Selinsing Canal and Main Canal, for paddy irrigation (Ismail and Najib, 2011; DID, 2012). The main purposes of Bukit Merah Reservoir are to provide irrigation water for double cropping to 24,000 ha of paddy land under the Krian Irrigation Scheme and for domestic water supply. Bukit Merah Reservoir is also well-known as a sanctuary for a species of highly commercially valuable fish, Malayan Golden Arowana (Scleropages formosus Müller and Schlegel, 1844) and as a northern lakefront resort and water park (Bukit Merah Laketown Resort) that supports ecotourism.

The reservoir has a storage of 74.98 million cubic meters, maximum spillway discharge of $424.7 \mathrm{~m}^{2}$ and its length and width are $13.8 \mathrm{~km}$ and $4.5 \mathrm{~km}$, respectively (DID, 2012). The reservoir comprises of spillway and intake structures. The spillway structure is used to safely convey discharge or release floods so that the water does not exceed the reservoir limit, while the intake is a structure used to release water for paddy irrigation and domestic water supply. In most parts, the reservoir is quite shallow (about three meters), though at the spillway and intake structures the depth is nearer to five meters. The water level of the reservoir is controlled by two main factors: climatic conditions and the outflow of water to irrigate paddy fields (DID, 2012). The catchment areas of BMR include the virgin and primary forest, agriculture (palm oil plantation) and a breeding farming industry (national boer breeding centre) for economical purposes.

The study area consisted of four sampling sites to represent different ecological conditions within the same system. Site $1\left(05^{\circ} 01^{\prime} 56.4^{\prime \prime} \mathrm{N}, 100^{\circ} 40^{\prime} 04.3^{\prime \prime} \mathrm{E}\right)$ was located at the outlet of the Kurau River basin, Site $2\left(04^{\circ} 59^{\prime} 48.0^{\prime \prime} \mathrm{N}, 100^{\circ} 41^{\prime} 14.5^{\prime \prime} \mathrm{E}\right)$ was located in the outlet of the river area that far from the, while Site $3\left(05^{\circ} 01^{\prime} 04.2^{\prime \prime} \mathrm{N}, 100^{\circ} 39^{\prime} 20.3^{\prime \prime} \mathrm{E}\right)$ and Site $4\left(05^{\circ} 01^{\prime} 52.1^{\prime} \mathrm{N}, 100^{\circ} 39^{\prime} 12.3^{\prime \prime} \mathrm{E}\right)$ were located at the irrigation canal and gated spillway structures, respectively (Fig. 1).

Sampling was carried out monthly at the four sites from January to April 2013. The sampling months were grouped into two seasons (wet and dry) based on the mean rainfall data of last 10 years (source from the Malaysian Meteorological Department). The season was characterized by monthly rainfall ranging from 150 to $300 \mathrm{~mm}$ during wet season and 0 to 150 mm during dry season. Fish sampling was conducted monthly by using experimental mesh gill-nets ranging from 2.5 to $13 \mathrm{~cm}$ in size. All of the fish caught were preserved in an ice chest during transportation to the laboratory. In the laboratory, the fish were counted, their body length and weight measured and identified to the lowest taxa possible using standard taxonomic keys (Kottelat et al., 1993; Rainboth, 1996; Ambak et al., 2010) before being preserved in $10 \%$ formalin. Voucher specimens were then catalogued and kept at the School of Biological Sciences, University Sains Malaysia. The physico-chemical parameters of the water were measured using YSI 56, and secchi disc. The variables measured were dissolved oxygen (DO, mg/l), temperature $\left({ }^{\circ} \mathrm{C}\right), \mathrm{pH}$, water conductivity $(\mu \mathrm{S} / \mathrm{cm})$, total dissolved solids (TDS, $\mathrm{mg} / \mathrm{l})$ and water clarity $(\mathrm{cm})$. 


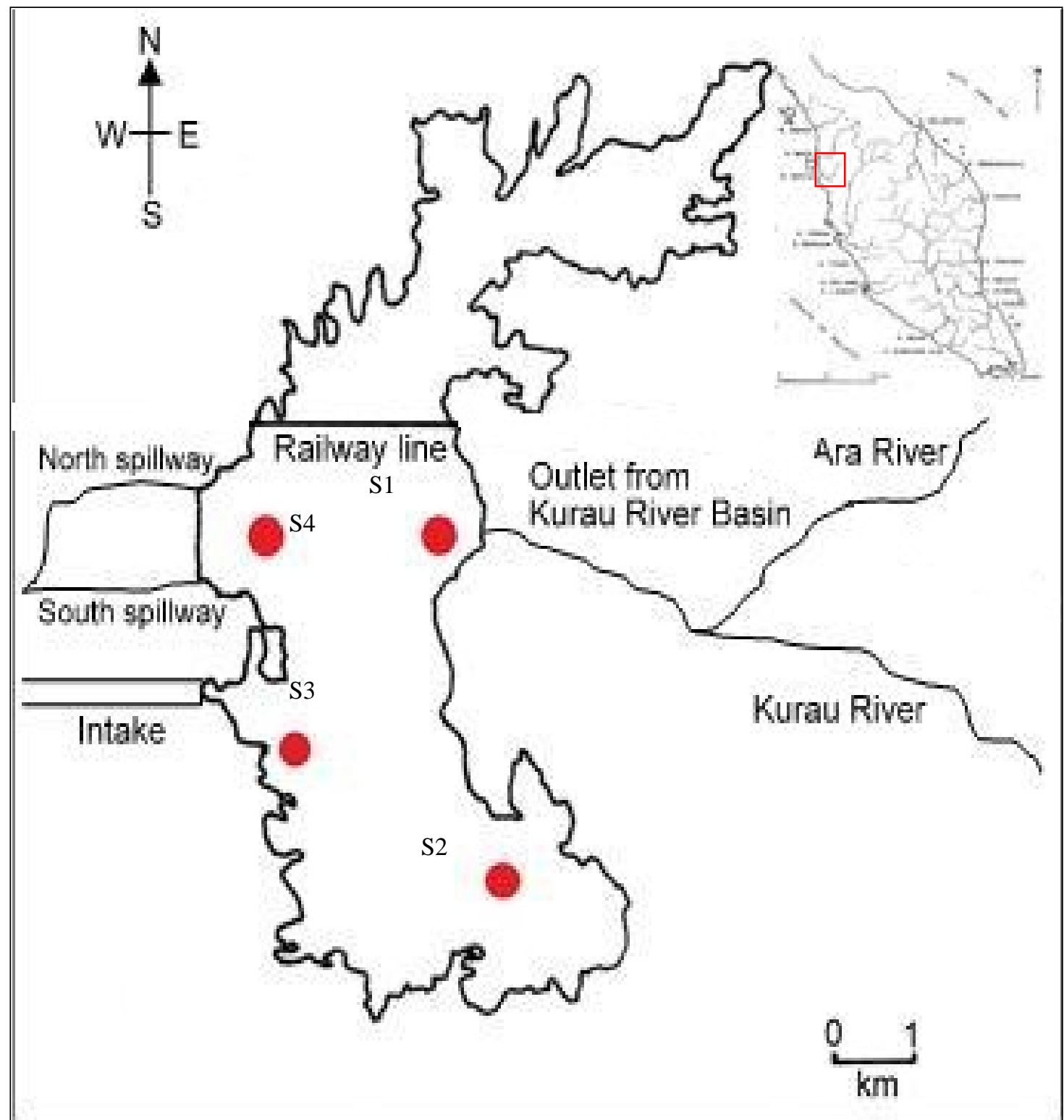

Figure 1: Bukit Merah Reservoir (BMR) system with four sampling sites (S1, S2, S3 and S4).

Catch per Unit Effort (CPUE) was used to estimate fish abundance and biomass from different seasons and sampling sites, which is defined as the sum of the total number (CPUEn) and weight (CPUEb) of captured fish per 24 hours (sampling effort). The values of both CPUE were then transformed into $\log _{10}$ (CPUE +1 ) to stabilize the variance for statistical comparison analysis. Species diversity for each sampling site was measured using the Shannon Index while species richness was compared among sampling sites by using rarefaction of individual samples from the program EcoSim 7.0 (Gotelli and Entsminger, 2001). Comparisons among season and sites were made by using a T-test analysis and one-way analysis of variance (ANOVA), respectively. 


\section{RESULTS}

A total of 19 species belonging to 10 families were recorded during the study (Tab. 1). Eight species that had more than $1 \%$ of the numerical abundance contributed $97.08 \%$ of the total catch in number of individuals and $89.03 \%$ of the total biomass. Oxygaster anomalura had the highest abundance of $27.63 \%$, followed by Notopterus notopterus (17.34\%), Barbonymus gonoinotus (16.94\%) and Cyclocheilichthys apogon (11.75\%). While other species were frequent, their numbers collected were very much less. However, the greatest biomass was recorded by $N$. notopterus, which contributed to $30.67 \%$ of the total weight.

Table 1: Fish checklist by sampling sites with their percentage of numerical abundance and biomass in Bukit Merah Reservoir, Malaysia; notes: + = present; - = absent.

\begin{tabular}{|l|l|c|c|c|c|c|c|}
\hline \multirow{4}{*}{ Family } & \multicolumn{1}{|c|}{ Species } & S1 & S2 & S3 & S4 & $\begin{array}{c}\text { Numerical } \\
\text { abundances } \\
(\%)\end{array}$ & $\begin{array}{c}\text { Biomas } \\
(\%)\end{array}$ \\
\hline Bagridae & Hemibagrus nemurus & - & - & + & + & 0.24 & 0.52 \\
\hline Clariidae & Clarias gariepinus & + & + & - & - & 0.24 & 1.58 \\
\hline Channidae & Channa micropeltes & - & - & + & - & 0.08 & 0.55 \\
\hline Cichlidae & Oreochromis niloticus & + & - & - & + & 0.49 & 3.72 \\
\hline \multirow{5}{*}{ Cyprinidae } & Cyclocheilichthys apogon & + & + & + & + & 11.75 & 4.03 \\
\cline { 2 - 9 } & Barbonymus gonionotus & + & + & + & + & 16.94 & 19.53 \\
\cline { 2 - 9 } & Barbonymus schwanenfeldi & + & + & + & + & 9.97 & 11.30 \\
\cline { 2 - 9 } & Hampala macrolepidota & + & + & + & + & 2.43 & 3.79 \\
\cline { 2 - 9 } & Labiobarbus leptocheilus & - & + & + & - & 0.57 & 1.31 \\
\cline { 2 - 9 } & Osteochilus vittatus & + & + & + & + & 7.21 & 5.18 \\
\cline { 2 - 9 } & Oxygaster anomalura & + & + & + & + & 27.63 & 17.34 \\
\cline { 2 - 9 } & Systomus orphoides & - & - & + & - & 0.16 & 0.23 \\
\cline { 2 - 9 } & Thynnichthys thynnoides & + & - & - & - & 0.73 & 2.72 \\
\hline Eleotridae & Oxyeleotris marmoratus & - & - & - & + & 0.08 & 0.09 \\
\hline Helostomatidae & Helostoma temminckii & + & + & + & - & 3.81 & 7.19 \\
\hline Notopteridae & Notopterus notopterus & + & + & + & + & 17.34 & 20.67 \\
\hline Osphronemidae & Osphronemus goramy & + & + & - & - & 0.16 & 0.14 \\
\cline { 2 - 8 } & Trichopodus pectoralis & + & - & - & - & 0.08 & 0.08 \\
\hline Siluridae & Ompok siluroides & + & - & - & - & 0.08 & 0.02 \\
\hline
\end{tabular}

Among all sampling sites, S1 had the highest diversity index value of 2.06, and S4 scored the least (1.46), while S2 and S3 had 1.82 and 1.79, respectively. Based on the rarefaction curves, the species richness expected for a standard sample of 191 individuals was 12 for S1, 10 species for S2, 11 species for S3 and 10 species for S4 (Fig. 2). However, species diversity and richness were not significantly different among sites and season $(p>0.05)$. 


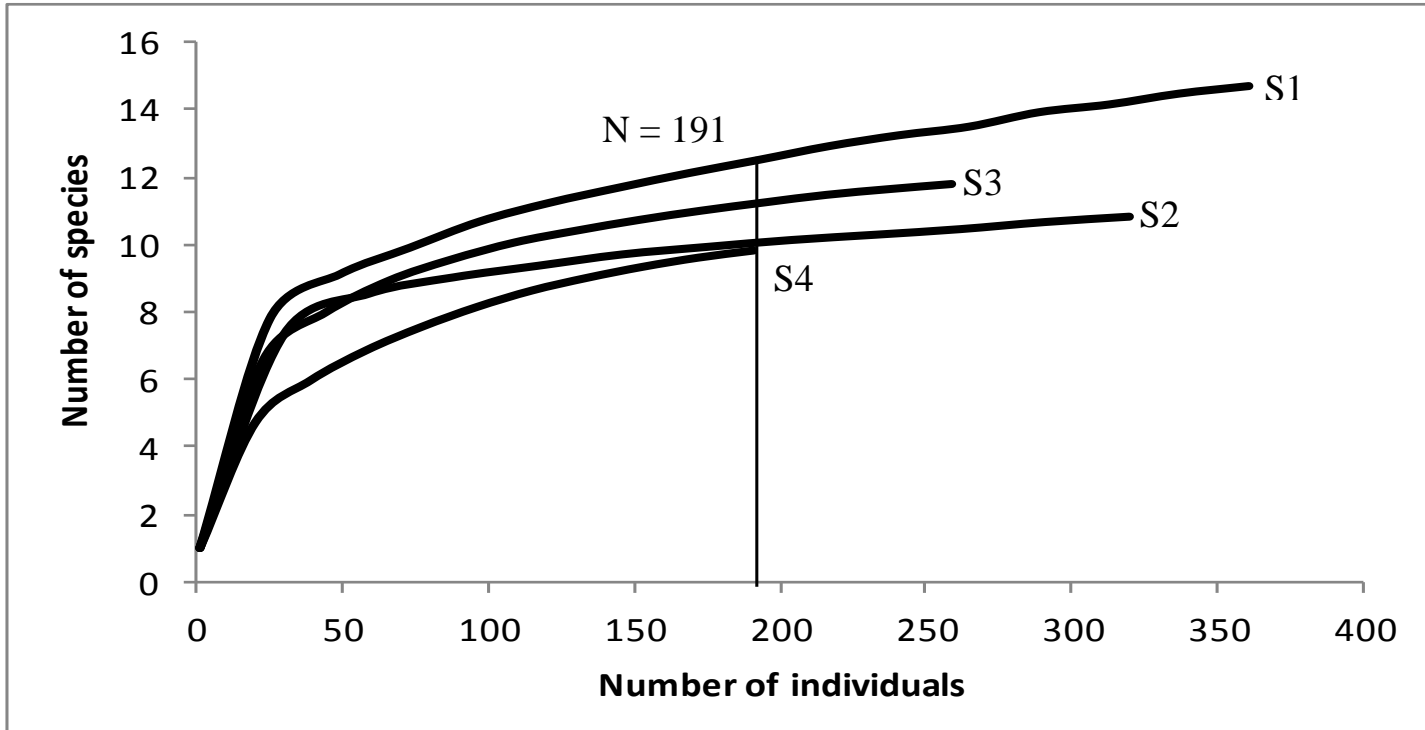

Figure 2: Individual-based rarefaction curves by sites (S1 to S4) for species richness in Bukit Merah Reservoir. Standard sample of individuals was labelled as N = 191.

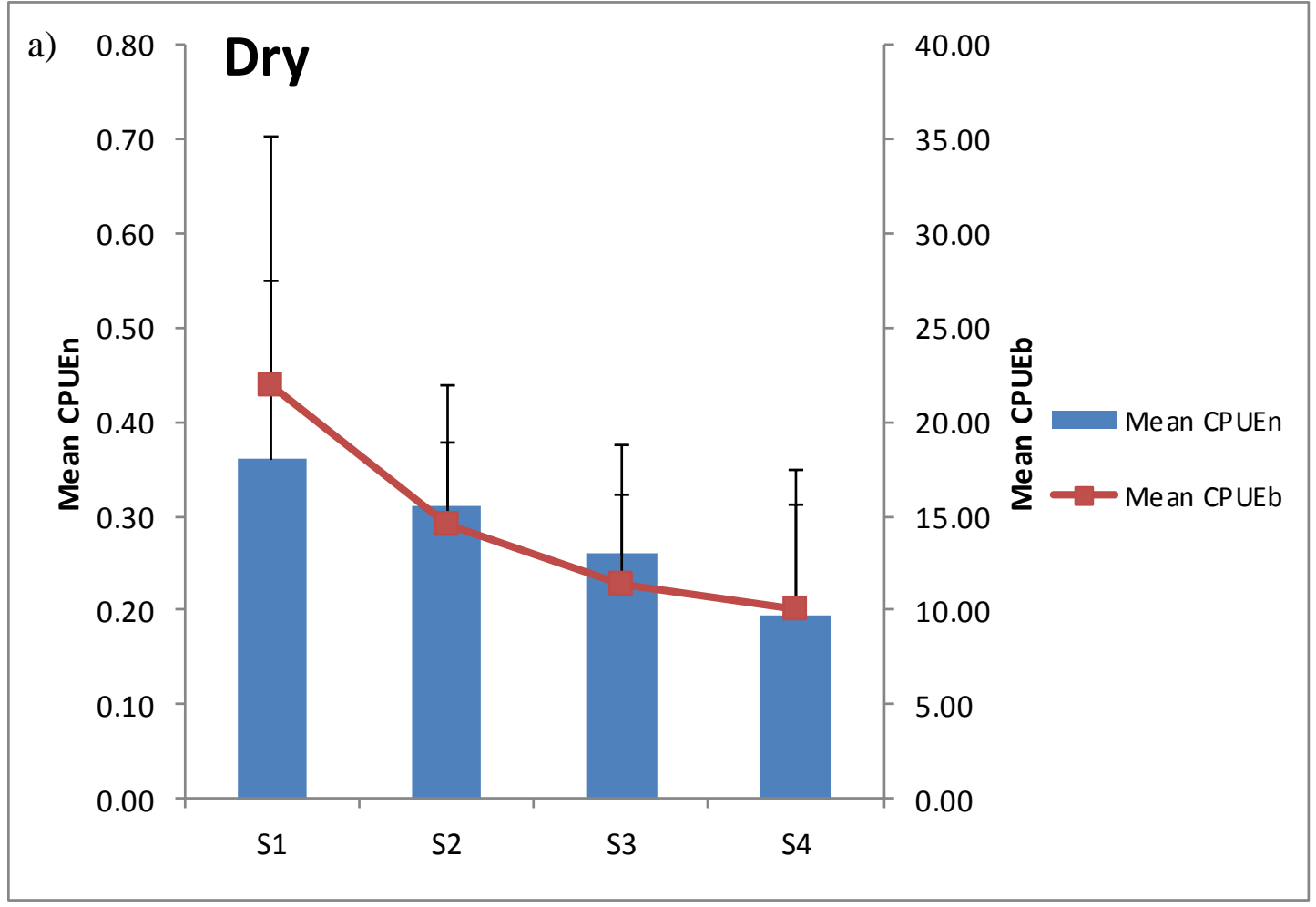

Figure 3a: Mean abundance (CPUEn \pm s.e.) and biomass (CPUEb \pm s.e.) of spatial and seasonal variations in Bukit Merah Reservoir, Perak, Malaysia. 


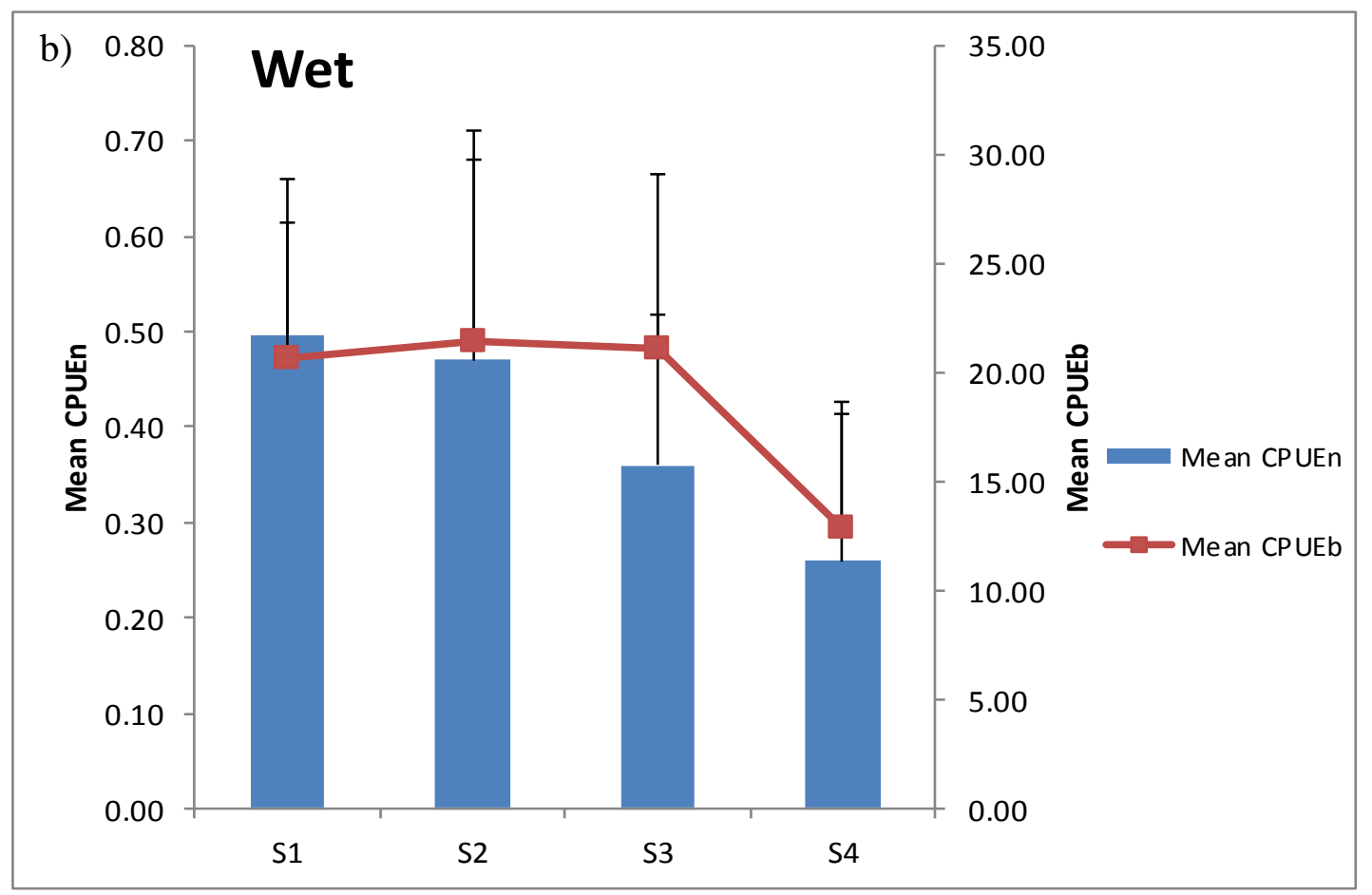

Figure 3b: Mean abundance (CPUEn \pm s.e.) and biomass (CPUEb \pm s.e.) of spatial and seasonal variations in Bukit Merah Reservoir, Perak, Malaysia.

Changes in mean CPUEn and CPUEb were observed between seasons and sampling sites (Figs. 3a, b). Both seasons showed similar patterns in mean CPUE values, decreasing of mean CPUEn values from S1 to S4. Site 1 recorded the highest mean CPUEn values of $0.36 \pm$ 0.19 during the dry season and $0.50 \pm 0.16$ during the wet season, while the lowest mean CPUEn were recorded in S4 with the values of $0.2 \pm 0.12$ and $0.26 \pm 1.56$ during the dry and wet season, respectively. The CPUEn values for S2 were $0.31 \pm 0.13$ (dry) and $0.47 \pm 0.21$ (wet) while the values for S3 were $0.26 \pm 0.12$ (dry) and $0.36 \pm 0.16$ (wet). A similar pattern was found for the mean CPUEb during the dry season, with the highest mean being recorded in S1 (21.96 \pm 13.14), followed by S2 (14.57 \pm 4.36), S3 (11.44 \pm 4.75$)$ and S4 (10.01 \pm 7.43$)$. However, during the wet season, the mean CPUEb for S1 (20.65 \pm 6.25$)$, S2 (21.40 \pm 9.7$)$ and S3 $(21.07 \pm 8.05)$ were less varied, except for S4 (12.90 \pm 5.8$)$. Based on a mean comparison of T-test analysis, there was a significant difference of mean CPUEn $(t=3.77, d f=11, p<$ $0.05)$ and CPUEb $(t=2.50, d f=11, p<0.05)$ during both seasons. However, there was no significant difference found among sites, although the variation for both mean CPUEn and CPUEb were observed among sites.

Concentration of DO content in the reservoir was less varied, from $5.06 \pm 0.52 \mathrm{mg} / \mathrm{l}$ (wet season, Site 4) to $6.28 \pm 0.55 \mathrm{mg} / \mathrm{l}$ (dry season, Site 3) with no significant difference among the seasons and the sampling sites. Water temperature showed an increasing trend from dry to wet seasons, which was statistically significant between both seasons $(t=4.93, d f=14$, $p=0.00$ ), ranging from $24.51 \pm 1.28^{\circ} \mathrm{C}$ (dry season, Site 1) to $29.48 \pm 0.59^{\circ} \mathrm{C}$ (wet season, Site 2). However, there were no differences found in water temperature among the sampling sites. The $\mathrm{pH}$ values were significantly higher during the wet season compared to the dry season, 
ranging between 5.73 to $7.19(t=2.39, d f=14, p=0.031)$. Water conductivity showed a different seasonal pattern, with increasing values from the dry to the wet season $(t=3.22, d f=$ $14, p=0.013$ ), ranging from $14.67 \pm 0.33 \mu \mathrm{S} / \mathrm{cm}$ (dry season, Site 3 ) to $19.67 \pm 2.19 \mu \mathrm{S} / \mathrm{cm}$ (wet season, Site 1). The mean TDS values fell into small range, from $13 \pm 0.58 \mathrm{mg} / \mathrm{l}$ (dry season, Site 3) to $14.67 \pm 0.33 \mathrm{mg} / \mathrm{l}$ (wet season, Site 1 ). The TDS values were significant among sampling sites $(F(3.12)=4.316, p=0.028)$. A Tukey post-host test found that only S1 and S3 were significantly different $(p<0.05)$. Water clarity showed large variations, ranging from $33 \pm 0.14 \mathrm{~cm}$ (wet season, Site 1) to $93.5 \pm 4.37 \mathrm{~cm}$ (wet season, Site 2). The large variation of this parameter, leading to a significant different among the sampling sites ( $F$ (3.12) $=4.381, p=0.027$ ), indicates that the clarity of water was significantly different between the outlet of Kurau River basin and the area with high aquatic plants $(p<0.05)$ (Tab. 2).

Table 2: Physico-chemical parameters (mean \pm s.e.) from four sampling sites of Bukit Merah Reservoir during dry and wet season.

\begin{tabular}{|c|c|c|c|c|c|c|c|}
\hline Season & Site & DO (mg/l) & $\begin{array}{l}\text { Temp. } \\
\left({ }^{\circ} \mathrm{C}\right)\end{array}$ & $\mathrm{pH}$ & $\begin{array}{l}\text { Conduct. } \\
(\mu \mathrm{S} / \mathrm{cm})\end{array}$ & $\begin{array}{l}\text { TDS } \\
(\mathrm{mg} / \mathrm{l})\end{array}$ & $\begin{array}{c}\text { Water } \\
\text { clarity }(\mathrm{cm} \\
\text { ) }\end{array}$ \\
\hline \multirow{4}{*}{ Dry } & 1 & $\begin{array}{c}5.91 \pm \\
1.21\end{array}$ & $\begin{array}{c}24.51 \pm \\
1.28 \\
\end{array}$ & $\begin{array}{c}5.98 \pm \\
0.27\end{array}$ & $\begin{array}{c}16.33 \pm \\
0.33\end{array}$ & $\begin{array}{c}14.33 \pm \\
0.33\end{array}$ & $\begin{array}{c}57.67 \pm \\
8.29\end{array}$ \\
\hline & 2 & $\begin{array}{c}5.20 \pm \\
0.76\end{array}$ & $\begin{array}{c}24.60 \pm \\
0.33\end{array}$ & $\begin{array}{c}6.79 \pm \\
0.18\end{array}$ & $\begin{array}{l}16 \pm \\
0.01\end{array}$ & $\begin{array}{l}14 \pm \\
0.01\end{array}$ & $\begin{array}{c}92.33 \pm \\
8.54\end{array}$ \\
\hline & 3 & $\begin{array}{c}6.28 \pm \\
0.55\end{array}$ & $\begin{array}{c}25.21 \pm \\
1.14\end{array}$ & $\begin{array}{c}5.76 \pm \\
0.31\end{array}$ & $\begin{array}{c}14.67 \pm \\
0.33\end{array}$ & $\begin{array}{l}13 \pm \\
0.58\end{array}$ & $\begin{array}{c}92.67 \pm \\
7.65\end{array}$ \\
\hline & 4 & $\begin{array}{c}6.21 \pm \\
0.91\end{array}$ & $\begin{array}{c}25.13 \pm \\
0.44\end{array}$ & $\begin{array}{c}5.73 \pm \\
0.26\end{array}$ & $\begin{array}{l}17 \pm \\
0.01\end{array}$ & $\begin{array}{l}14 \pm \\
0.01\end{array}$ & $\begin{array}{c}77.5 \pm \\
6.06\end{array}$ \\
\hline \multirow{4}{*}{ Wet } & 1 & $\begin{array}{c}5.62 \pm \\
0.53\end{array}$ & $\begin{array}{c}28.34 \pm \\
0.96\end{array}$ & $\begin{array}{c}6.58 \pm \\
0.42\end{array}$ & $\begin{array}{c}19.67 \pm \\
2.19\end{array}$ & $\begin{array}{c}14.67 \pm \\
0.33\end{array}$ & $\begin{array}{l}33 \pm \\
0.14\end{array}$ \\
\hline & 2 & $\begin{array}{c}5.32 \pm \\
0.36\end{array}$ & $\begin{array}{c}29.48 \pm \\
0.59\end{array}$ & $\begin{array}{c}7.19 \pm \\
0.42\end{array}$ & $\begin{array}{l}19 \pm \\
2.31\end{array}$ & $\begin{array}{c}13.33 \pm \\
0.33\end{array}$ & $\begin{array}{c}93.5 \pm \\
4.37\end{array}$ \\
\hline & 3 & $\begin{array}{c}5.97 \pm \\
0.40\end{array}$ & $\begin{array}{c}29.18 \pm \\
0.49\end{array}$ & $\begin{array}{c}6.84 \pm \\
0.44\end{array}$ & $\begin{array}{c}18.67 \pm \\
2.19\end{array}$ & $\begin{array}{l}14 \pm \\
0.01\end{array}$ & $\begin{array}{c}81.88 \pm \\
12.70\end{array}$ \\
\hline & 4 & $\begin{array}{c}5.06 \pm \\
0.52\end{array}$ & $\begin{array}{c}28.88 \pm \\
0.61\end{array}$ & $\begin{array}{c}6.51 \pm \\
0.43\end{array}$ & $\begin{array}{l}19 \pm \\
2.52\end{array}$ & $\begin{array}{c}14.33 \pm \\
0.33\end{array}$ & $\begin{array}{c}66.25 \pm \\
12.99\end{array}$ \\
\hline
\end{tabular}

\section{DISCUSSION}

Based on the numerical abundance, eight species were commonly found in the reservoir, in which six of them (Oxgaster anomalura, Cyclocheilichthys apogon, Barbonymus gonionotus, Barbonymus schwanenfeldii, Hampala macrolepidota and Osteochilus vittatus) were from family Cyprinidae. In Southeast Asia, the Cyprinidae family was the most dominant in both lotic and lentic water bodies, because it consists of many species (Zakaria, 1994). Chong et al., (2010), with about 150 species in Malaysia alone. The dominance of cyprinids in local reservoirs were recorded in Subang Reservoir, Selangor (42\%) (Yap, 1992), Temengor Reservoir, Perak (57\%) (Zakaria and Lim, 1995), and Kenyir Reservoir, Terengganu (57\%) (Yusoff et al., 1995; Kamaruddin et al., 2011). The dominance of O. anomalura, C. apogon, $B$. gonionotus, B. schwanenfeldii, $H$. macrolepidota and O. vittatus, $N$. notopterus and Helostoma temminckii indicated that they thrive well in lentic water body as they contributed $97.08 \%$ of the total catch. These species were also dominant in Chenderoh Reservoir, Malaysia (Kah-Wai and Ali, 2001). 
Although there was no significant difference in fish diversity among sites, fish assemblage in the reservoir was different spatially, with greater species richness and diversity observed in the area where the influence of the river is the greatest. The ecotone of river and reservoir, or transitional zone, contributes to the increase of fish diversity due to high abundance of submerged and floating macrophytes that increase spatial heterogeneity and feeding resource availability (Lowe-McConnell, 1991; Aliko et al., 2010; Terra et al., 2010).

The fish community in BMR has distinct seasonal variations. The number of individuals and their biomass caught (CPUEn and CPUEb) during wet season were higher than in dry season. In tropical countries, wet season indicates the main feeding and growing time for the fish (Rainboth, 1996; Meye and Ikomi, 2012). The similar trend was also reported in Kenyir Lake, in which the CPUE was higher during the rainy season compared to the dry season (Kamaruddin et al., 2011). The CPUE data was influenced by the catchability of the gear, location of the sampling and the abundance of the fish in that area (Abiodun and Miller, 2007). The littoral zone had the highest fish catch value, because most of the fish stay close to the shore and were commonly found feeding on the surface of the littoral zone in the reservoir (Fernando and Holčík, 1991; Ali, 1996; Ambak and Jalal, 2006). The inundation of littoral areas that rich the aquatic and terrestrial vegetation during the wet season increase the availability of food resources and thus enables a large number of fish species to occupy those areas. Generally, fish that inhabit reservoirs were formerly riverine species that depended on terrestrial and aquatic vegetation such as ripe fruits, seeds, terrestrial and aquatic insects for food (Ambak and Jalal, 2006). Bishop and Forbes (1991) also found a significant positive correlation between aquatic vegetation and fish diversity. However, the decreasing of CPUEn and CPUEb during the dry season was influenced by the increasing number of fishing occurrences by full and part-time local fishermen hence reducing the fish collection during the sampling. A greater and easier accessibility into the water body due to reduced water volume contributed to the increase of fishermen (Allison et al., 1997). Arcifa and Meschiatti (1993) concluded that the fish population was concentrated in the shallow areas during the wet season and moved to the open area during the dry season.

From the results of physico-chemical parameters, all the parameter values were quite similar with other major reservoirs in Malaysia (Ambak and Jalal, 2006). However, because of the shallowness of the reservoir, the values of those parameters were less varied among sites, although they showed a significant difference spatio-temporally. One possible explanation could be that all sampling sites are located in the same geographical zone and sampling was done in the same environmental conditions. The range of water level did not vary much due to the release of water through spillway to maintain the reservoir level and for paddy irrigation from the Selinsing Canal intake. Dissolved oxygen (DO) showed no significant difference among sites, and seasons indicate that BMR has a uniform reading of oxygen concentration in the water. The concentration of DO in the water lies within the optimum range of fish health (Jain et al., 1977; Alabaster and Lloyd, 1982). Temperature was higher during the wet season than in dry season. The water temperature increasing during the wet season was also recorded in Three Gorges Reservoir, China (Chen et al., 2013) and in Itupararanga Reservoir, Brazil (Pedrazzi et al., 2013). Weather conditions during the sampling influenced the reading of the water temperature (Pedrazzi et al., 2013). The water temperature in BMR provides optimum growth for the fish which ranged between $25-30^{\circ} \mathrm{C}$ (Afzal Khan et al., 2004). 
Pedrazzi et al. (2013) also recorded higher $\mathrm{pH}$ values during the wet season, similar with the present study. Photosynthetic activity may increase the $\mathrm{pH}$ values in the reservoir (Pedrazzi et al., 2013). Climatic condition, such as rainfall that occurred during the sampling, influenced the values of some parameters. For example, surface runoff that contained large nutrients during the wet season was probably one of the factors that increased the water conductivity in the reservoir (Terra et al., 2010). However, the values were still within the normal range for fresh water (10-1,000 $\mu \mathrm{S} / \mathrm{cm})$ (Offem et al., 2011).

\section{CONCLUSIONS}

Increased abundance and biomass during the wet season suggests that new microhabitats become available for fish in the floodplain areas, and fish in both lotic and lentic habitats used littoral habitats within river-reservoir interfaces and migrated through the ecotone during the wet season.

The reservoir showed less variation for its physico-chemical parameters, although there were significant differences during both seasons and sampling sites.

Generally, the reservoir is relatively small, with its depth ranging from three to five meters.

The water fluctuation did not vary much due to the withdrawal of water to maintain its reservoir limit, for paddy irrigation and domestic water supply, resulting in less variation in the mean values of most parameters.

From the result, most of the parameters fell within the suitable range for the aquatic life.

\section{ACKNOWLEDGEMENTS}

We would like express deep sense of gratitude to the Kerian Department of Irrigation and Drainage, Perak for their hospitalities, University Sains Malaysia, Penang for their funding of the project under research university grant (1001/PBIOLOGI/815092) and the Ministry of Higher Education for sponsorship under MyBrain15 MyPhD.

Finally, we would like to thank individuals who are directly and indirectly involved in this research, particularly those who helped in the collection of fish and related data in the field. 


\section{REFERENCES}

1. Abiodun J. A. and Miller J. W., 2007 - Assessment of Gerio Lake fishery for enhancement management and improved fish production, Journal of Applied Science and Environmental Management, 11, 4, 11-14.

2. Afzal Khan M., Jafri A. K. and Chadha N. K., 2004 - Growth and body composition of rohu, Labeo rohita (Hamilton), fed compound diet: winter feeding and rearing to marketable size, Journal of Applied Ichthyology, 20, 265-270.

3. Akinbile C. O., Yusoff M. S., Abu Talib S. H., Abu Hasan Z., Ismail W. R. and Sansudin U., 2013 - Qualitative analysis and classification of surface water in Bukit Merah Reservoir in Malaysia, Water Science and Technology Water Supply 13, 4, 1138-1145.

4. Alabaster J. S. and Lloyd R., 1982 - Water quality criteria for freshwater fish, 2nd edition, Food and Agriculture Organization of the United Nations, Butterworth Scientific, London, 361.

5. Alang R. N. N. R., Jusoh W. F. A. W., Nur-Zati A. M. and Hashim N. R., 2010 - Ant diversity on Sonneratia caseolaris trees in Rembau-Linggi mangrove forest, Peninsular Malaysia, Transylvanian Review of Systematical and Ecological Research, The Wetlands Diversity, Curtean-Bănăduc et al. (eds), 10, 77-82.

6. Ali A. B., 1996 - Chenderoh Reservoir, Malaysia: The conservation and wise use of fish biodiversity in a small flow-through tropical reservoir, Lakes and Reservoirs: Research and management, 2, 17-30.

7. Aliko N. G., Da Costa K. S., Konan K. F., Outtara A. and Gourene G., 2010 - Fish diversity along the longitudinal gradient in a man-made lake of West Africa, Taabo Hydroelectric Reservoir, Ivory Coast, Ribarstvo, 68, 2, 47-60.

8. Allison M. E., Gabriel U., Inko-Tariah M. B., Davies O. A. and Udeme-Naa B., 1997 - The fish assemblage of Elechi Creek, Rivers State, Nigeria, Niger Delta Biologia, 2, 90-96.

9. Ambak M. A. and Jalal K. C. A., 2006 - Sustainability issues of reservoir fisheries in Malaysia, Aquatic Ecosystem Health and Management, 9, 2, 165-173.

10. Ambak M. A., Isa M. M., Zakaria M. Z. and Ghaffar M. A., 2010 - Fishes of Malaysia, Penerbit University Malaysia Terengganu, 334.

11. Aziz T. N. A. and Hashim N. R., 2011 - Heavy metal concentrations in an important mangrove palm (Nypa fruticans), in Rembau-Linggi Mangrove Forest (Peninsular Malaysia), Transylvanian Review of Systematical and Ecological Research, The Wetlands Diversity, Curtean-Bănăduc et al. (eds), 12, 111-116.

12. Arcifa M. S. and Meschiatti A. G., 1993 - Distribution and feeding ecology of fishes in a Brazilian Reservoir: Lake Monte Alegre, Interciencia, 18, 6, 83-87.

13. Bishop K. A. and Forbes M. A., 1991 - The freshwater fishes of northern Australia, in Haynes C. D., Ridpath M. G. and Williams M. A. J. (eds), Monsoonal Australia: Landscape, ecology and man in the northern lowlands, A. A. Balkema, Rotterdam and Brookfield, 79-107.

14. Chen Z., Zhou Z., Peng X., Xiang H., Xiang S. and Jiang Z., 2013 - Effects of wet and dry seasons on the aquatic bacterial community structure of the Three Gorges Reservoir, World Journal of Microbiology and Biotechnology, 29, 841-853.

15. Chong V. C., Lee P. K. Y. and Lau C. M., 2010 - Diversity, extinction risk and conservation of Malaysian fishes, Journal of Fish Biology, 76, 2009-2066.

16. Department of Irrigation and Drainage, DID, 2012 - Bukit Merah Dam (Online), (Assessed 20th September 2012), Available from World Wide Web: http://www.water.gov.my.

17. Easton Z. M. and Petrovic A. M., 2004 - Fertilizer source effect on ground and surface water quality in drainage from turf grass, Journal of Environmental Quality, 33, 2, 645-655.

18. Fernando C. H. and Holčík J., 1991 - Fish in reservoirs, Internationale Revue der gesamten Hydrobiologie und Hydrographie, 76, 149-167.

19. Gotelli N. J. and Entsminger G. L., 2001 - EcoSim: Null models software for ecology, Version 7.0., Acquired Intelligence Inc. and Kesey-Bear, http://homepages.together.net/ $\sim$ gentsmin/ecosim.htm 
20. Ismail W. R. and Najib S. A. M., 2011 - Sediment and nutrient balance of Bukit Merah Reservoir, Perak (Malaysia), Lakes and Reservoirs: Research and Management, 16, 179-184.

21. Jain R. K., Urban L. V. and Stacey G. S., 1977 - Environmental impact analysis. A new dimension of decision making, New York: Van Nostrand Reinhold Company.

22. Kah-Wai K. and Ali A., 2001 - Chenderoh Reservoir, Malaysia: Fish community and artisanal fishery of a small mesotrophic tropical reservoir, 167-178, in Sena S. De Silva (ed.), Reservoir and culture based fisheries: biology and management, Australian centre for International Agricultural Research (ACIAR) Proceedings, 98, 167-178.

23. Kamaruddin I. S., Mustafa Kamal A. S., Christianus A., Daud S. K. and Yu Abit L., 2011 Fish community in Pengkalan Gawi - Pulau Dula Section of Kenyir Lake, Terengganu, Malaysia, Journal of Sustainability Science and Management, 6, 1, 89-97.

24. Kottelat M., Whitten A. J., Kartikasari S. N. and Wirjoatmodjo S., 1993 - Freshwater fishes of Western Indonesia and Sulawesi, Singapore: Periplus Editions Limited, 293.

25. Lowe-McConnell R. H., 1991 - Ecological studies in tropical fish communities, Cambridge, Cambridge University Press, 382.

26. Meye J. A. and Ikomi R. B., 2012 - Seasonal fish abundance and fishing gear efficiency in River Orogodo, Niger Delta, Nigeria, World Journal of Fish and Marine Sciences, 4, 2, 191200.

27. Offem B. O., Ayotunde E. O., Ikpi G. U., Ochang S. N. and Ada F. B., 2011 - Influence of seasons on water quality, abundance of fish and plankton species of Ikwori Lake, South-Eastern Nigeria, Fisheries and Aquaculture Journal, 1-18.

28. Pedrazzi F. J. D. M., Conceição F. T. D., Sardinha D. D. S., Moschini-Carlos V. and Pompêo M., 2013 - Spatial and temporal quality of water in the Itupararanga Reservoir, Alto Sorocaba Basin (SP), Brazil, Journal of Water Resource and Protection, 5, 64-71.

29. Sharip Z. and Zakaria S., 2008 - Lake and Reservoir in Malaysia: Management and Research Challenge, The National Hydraulics Research Institute of Malaysia, Seri Kembangan, Malaysia, 265.

30. Terra B. D. F., Santos A. B., and Araújo F. G., 2010 - Fish assemblage in a dammed tropical river: an analysis along the longitudinal and temporal gradients from river to reservoir, Neotropical Ichthyology, 8, 3, 599-606.

31. Yap S. Y., 1992 - Inland capture fishery in Malaysia, in Indo-Pacific Fishery Commission, FAO Fishery Report, Baluyut E. A. (ed.), 458 Supplement, FIRI/R458, Rome, 25-46.

32. Yusoff F. M., Zaidi M. Z. and Ambak M. A., 1995 - Fishery and environmental management of Lake Kenyir, Malaysia, in Indo-Pacific Fishery Commision, FAO Report, Petr T. and Morris M. (eds), 512 Supplement, FIRI/R512 Supplement, Rome, 112-128.

33. Zakaria I. and Lim K. K. P., 1995 - The fish fauna of Tasik Temengor and its tributaries south of Banding, Hulu Perak, Malaysia, Malayan Nature Journal, 48, 318-332. 